\title{
街路除雪の経済効果推定に関する試論*
}

\section{A TENTATIVE ESSAY IN THE ECONOMIC EFFECT OF SNOW REMOVAL OF THE STREET NETWORK}

\section{1.はじめに}

現代の都市は情報の集積と管理機能，および商業的活 動の中心として存在する。ところがこれらの機能，ある いは活動はすべて交通によって保持されているから，都 市の生命は交通にかかっており，都市は交通の所産であ るといっても過言ではない。そのため, 一時的にせよ, 積雪などにより，交通がまひするとたちまち都市は活動 を停止し, 市民生活は混乱に落ち入る。それゆえに, 冬 季, 積雪のみられる都市においては, 巨額の費用を投し て除雪を実施し, 交通の確保をはかっているのである。

およそ，相当額の経費を支出する以上，その効果を測 ろうとするのは当然であり，またその結果を知ることに よってこそ，はじめて以降の経費支出がよりいっそう有 効になされ得るのである。しかし，ここに述べる街路除 雪については, 従来, 本格的に経済効果を計測しょうと する試みがなされなかった。その理由として次のような いくつかの事項をあげることができよう。

a）豪雪地帯は比較的人口が少なく，かつ交通量もわ ずかであった。

b) 冬期の積雪は当然のこととして, あきらめの感が 強加た。

c）冬期の産業活動は休止するものが多かったし，ま た産業の種類も，農業のように休止せざるを得ないもの が大部分であり, 計上される除雪費も少なかった。

d）経済効果を計測しながら，公共事業を進めるとい う習慣がなかった。

e）特に道路除雪は毎年のことではありながら，春に なれば自然に解消するもので，かつ具体的施設が残るも のではない。

f）容易に適用できる経済効果推定法が開発されてい ない。

ところが，近年になって豪雪地帯の地方都市にも人口

* 一部年次学術講演会 (昭 45.11) に発表

** 正会員 北海道大学助教授 工学部土木工学科

\section{五十嵐 日出:夫** \\ By Hideo Igarashi}

が集中し, モータリゼーションの進展に伴って, 道路交 通量は激増してきた。またそれらの稠密な人口を支える ため, 産業構造は変化し, 第一次産業より, 第二次産 業, 第三次産業へと大勢が移行して, 年中, 持続的に生 産活動が営まれるようになってきた。そのため, 冬期に おける道路除雪の重要性が増大し, これに投ぜられる費 用も次第に莫大となってきたのである。一方，投ぜられ る費用が大きくなると, 自然にその有効性が問われるこ とになり, 経済効果を計測しながら事業を進めなりれば ならないといら考え方が強くなってきたのである。しか し，まだこの経済効果の推定法は開発されていない。 特に道路除雪は都市, あるいはその周辺部において重大 であり, その効果のあらわれ方も複雑で, どちらかとい えば短期的なものであるから，在来の道路の経済効果推 定法の応用だけでは解決できない問題である。

この研究においては個々の経済効果を推定し, 合計す るという個別的推定法にはよらず, 経済効果の発生過程 を追って把握する総合的推定法の考え方により計算を進 めようとするものである。すなわち, 経済効果はその道 路を流れる交通流によって発生し, 道路背後圈に波及し て地域経済水準の上昇を促す。いいかえると道路を流れ る交通流と地域経済機構との関連において経済効果が発 生するのである ${ }^{1)}$ 。

筆者はこのことに着目して, 交通流の巨視的性質を詳 細に観察した結果, この中に交通仕事量が一定であるの ではないかといら仮定が成立することを確かめた。さら にこれと交通量一生産所得関数モデルとを組み合わせ て, 道路除雪の直接, および間接的便益を総合し, 貨幣 単位により推定することを試みた。除雪費用について も, 費目別に分けず, 一括計算し, 便益額との比をと り，経済効果を推定してみたのである。

\section{2. 街路除雪の経済効果推定の考え方}

一般に道路の経済効果推定は交通流システムと地域経 済システムとの関連として把握されているが, 街路除雪 
の場合もこれと同様に考えられる。すなわち, 街路の積 雪は交通流システムに負の変化を与え, この退化した交 通流システムは都市の経済水準の低下を誘引する。

ところが，街路除雪はこの交通流システムに与える負 の変化を押え, その結果として, 都市の経済水準の低下 を軽減する。これが街路除雪の経済効果である。それゆ えに, この研究においては, 第一に街路上の積雪が交通 流システムに与える負の変化を交通量の減少として捕 え, ついで第二に, この交通量の減少が市民生産所得の 創出にどのような影響をもたらすかを推定しようとする ものである。

\section{（1）積雪による交通量の減少}

平常， $i-j$ ゾーン間の交通は大部分が最短経路 $k$ によ っているが，積雪によりこれが途絶したり，あるいは渋 滞に落ち入ったりすると, 迂回路 $l$ にって交通が行な われるようになる。しかし，この迁回路 $l$ は最短経路 $k$ に比べて交通抵抗（たとえば，所要旅行時間などで表わ される）が大きいから，この抵抗を克服できない交通は 発生しなくなるであろう。したがって $k$ の途絶，ある いは渋滞によって $i-j$ 間の交通量は減少することにな る。

この減少交通量を計算するため, 札幌市の交通流につ いて次のような調查をしてみた。すなわち, 昭和 42 年 8 月 18 日（金）から，22日（火）までの土曜日，日曜 日を除く 3 日間, 全市 262 地点について, 午前 7 時よ り午後 7 時に至る 12 時間, 交通量調查を実施した。さ らに調查日と同じような道路条件の日を見計らって, 試 験車を用い走行速度調査を行なった ${ }^{2)}$ 。また翌, 昭和 43 年 1 月 8 日（月）から 11 日（木）までの 4 日間, 前年夏 期の調查地点のうち, オリンピック道路, および主要除 雪路線などを勘案した 112 地点について, 前回と同じ <午前 7 時より午後 7 時に至る 12 時間, 交通量を調查 し，さらに走行速度調查は同年 2 月に行なった。これら の資料のうちで夏期, および冬期の交通量, 走行速度調 查結果のそろっているものを選択し, 交通量 $T_{k}$ とそ れぞれの旅行時間 $t_{k}$ との積の和として定義した交通仕 事量 $\Sigma T_{k}$ • $t_{k}$ を次のような要領によって算出した（図

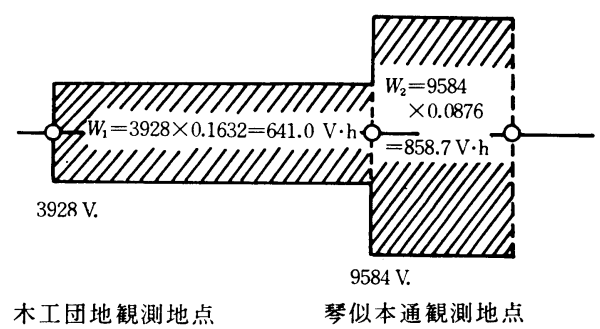

図一1＼cjkstart交通仕事基の計算方法
$-1)$ 。

a）地点交通量により交通流帯図をかく。

b) 区間距離を平均旅行速度で割って平均旅行時間を 算出する。

c）交通量（この場合は 12 時間往復地点通過台数を とった）に平均旅行時間をかけて，この区間の交通 仕事量（台・時）とする。

d）それぞれの区間の交通仕事量を全市について合計 し，札幌市に扔ける総交通仕事量とする。 その結果は 表一1 のとおりである。

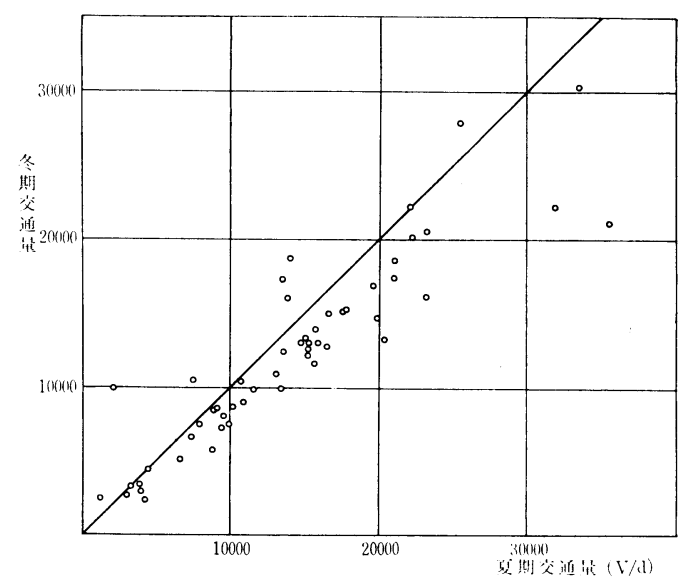

図一2夏期交通量と冬期交通量の比較

図一2 はそれぞれの地点における夏期交通量と冬期交 通量を比較したものであるが，予想されるとおり，ほと んどの路線について夏期交通量の方が冬期交通量より大 きい。しかし，ごく一部の路線については冬期交通量の 方が大きくなっている。これはよく除雪されている路線 へ，除雪されていない路線から転換してくるためであろ う。このような地点交通量の合計の比は夏期を 100 と すれば，冬期は 86.3 であり，およそ $13.7 \%$ の差がみ られる。一方，交通交事量についてみれば，各路線では 図一3 にみられるように，増減相半ばするが，合計では

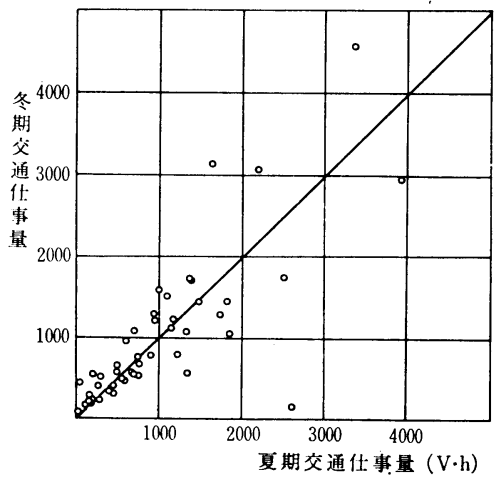

図一3夏期交通仕事量と冬期交通仕事且の比較 
表一1 札幌市における夏期交通仕事量と冬期交通仕事量との比較

\begin{tabular}{|c|c|c|c|c|c|c|c|c|c|c|}
\hline 観測地点名 & & 路 線 長 ${ }^{1)}$ & \begin{tabular}{l|} 
夏期平均 ${ }^{22}$ \\
区間速度
\end{tabular} & $\begin{array}{l}\text { 冬期平均 }{ }^{32} \\
\text { 区間速度 }\end{array}$ & $\begin{array}{l}\text { 夏 } \\
\text { 旅行時間 }\end{array}$ & $\begin{array}{l}\text { 冬 }{ }^{\text {期5) }} \\
\text { 旅行時間 }\end{array}$ & 夏期交通量6) & 冬期交通量 ${ }^{7)}$ & $\begin{array}{l}\text { 夏期交通 } \\
\text { 仕 } \\
\text { 事 量 }\end{array}$ & $\begin{array}{l}\text { 冬期交通9) } \\
\text { 仕 事 量 }\end{array}$ \\
\hline 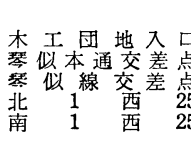 & & $\begin{array}{r}6250 \\
2750 \\
1950 \\
500 \\
3600\end{array}$ & $\begin{array}{l}38.3 \\
30.7 \\
29.7 \\
16.4 \\
33.1\end{array}$ & $\begin{array}{l}33.1 \\
24.9 \\
20.7 \\
20.8 \\
24.2\end{array}$ & $\begin{array}{r}\times 10^{-3} \\
163.2 \\
89.6 \\
65.7 \\
30.5 \\
108.8\end{array}$ & $\begin{array}{r}\times 10^{-3} \\
188.8 \\
110.4 \\
94.2 \\
24.0 \\
148.8\end{array}$ & $\begin{array}{r}3928 \\
9584 \\
21113 \\
15177 \\
4544\end{array}$ & $\begin{array}{r}3018 \\
7170 \\
18500 \\
13261 \\
4474\end{array}$ & $\begin{array}{r}641.0 \\
858.7 \\
1387.1 \\
462.9 \\
494.4\end{array}$ & $\begin{array}{r}569.8 \\
791.6 \\
1742.7 \\
318.3 \\
665.7\end{array}$ \\
\hline 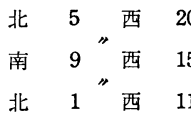 & & $\begin{array}{r}2450 \\
1750 \\
1150 \\
800 \\
1700\end{array}$ & $\begin{array}{l}37.5 \\
15.0 \\
27.5 \\
37.7 \\
25.8\end{array}$ & $\begin{array}{l}20.0 \\
19.3 \\
23.3 \\
32.6 \\
17.0\end{array}$ & $\begin{array}{r}65.3 \\
116.7 \\
41.8 \\
21.2 \\
65.9\end{array}$ & $\begin{array}{r}122.5 \\
90.7 \\
49.4 \\
24.5 \\
100.0\end{array}$ & $\begin{array}{r}15408 \\
15879 \\
7580 \\
7419 \\
21112\end{array}$ & $\begin{array}{r}12920 \\
11516 \\
10376 \\
6601 \\
17380\end{array}$ & $\begin{array}{r}1006.1 \\
1853.1 \\
316.8 \\
157.3 \\
1391.3\end{array}$ & $\begin{array}{r}1582.7 \\
1044.5 \\
512.6 \\
161.7 \\
1738.0\end{array}$ \\
\hline $\begin{array}{lccc}\text { 南 } & 2 \\
\text { 南 } & 14 & \text { 西 } & 1 \\
\text { 南 } & 22 & 1 \\
\text { 南 } & 22 & \text { 西 } & 1 \\
& & \text { 西 } & 1\end{array}$ & $\begin{array}{l}11 \\
11 \\
10 \\
11\end{array}$ & $\begin{array}{r}1350 \\
1950 \\
1900 \\
3100 \\
550\end{array}$ & $\begin{array}{l}36.0 \\
33.4 \\
23.9 \\
37.0 \\
27.5\end{array}$ & $\begin{array}{l}30.8 \\
25.4 \\
25.0 \\
33.4 \\
21.2\end{array}$ & $\begin{array}{l}37.5 \\
58.4 \\
79.5 \\
83.8 \\
20.0\end{array}$ & $\begin{array}{l}43.8 \\
76.8 \\
76.0 \\
92.8 \\
25.9\end{array}$ & $\begin{array}{r}25625 \\
19901 \\
3991 \\
8946 \\
13968\end{array}$ & $\begin{array}{r}27718 \\
14679 \\
3403 \\
8396 \\
15930\end{array}$ & $\begin{array}{r}960.9 \\
1162.2 \\
317.3 \\
749.7 \\
279.4\end{array}$ & $\begin{array}{r}1214.0 \\
1127.3 \\
258.6 \\
779.1 \\
412.6\end{array}$ \\
\hline $\begin{array}{cccc}\text { 北 } & 18 & \text { 西 } & 5 \\
\text { 南 } & \text { 通 } & \text { 西 } & 5 \\
\text { 南 } & 1 & \text { 西 } & 6 \\
\text { 南 } & 9 & \text { 西 } & 5 \\
\text { 西 } & 6\end{array}$ & $\begin{array}{l}5 \\
5 \\
6 \\
5 \\
6\end{array}$ & $\begin{array}{r}2300 \\
2050 \\
700 \\
750 \\
1150\end{array}$ & $\begin{array}{l}30.0 \\
15.8 \\
14.2 \\
32.5 \\
37.6\end{array}$ & $\begin{array}{l}23.7 \\
14.0 \\
12.7 \\
16.5 \\
21.7\end{array}$ & $\begin{array}{r}76.7 \\
129.7 \\
49.3 \\
23.1 \\
30.6\end{array}$ & $\begin{array}{r}97.0 \\
146.4 \\
55.1 \\
45.5 \\
53.0\end{array}$ & $\begin{array}{r}15354 \\
11545 \\
3413 \\
2110 \\
23371\end{array}$ & $\begin{array}{r}12481 \\
9885 \\
3340 \\
9941 \\
20394\end{array}$ & $\begin{array}{r}1177.7 \\
1497.4 \\
168.3 \\
48.7 \\
715.2\end{array}$ & $\begin{array}{r}1210.7 \\
1447.2 \\
184.0 \\
452.3 \\
1080.9\end{array}$ \\
\hline $\begin{array}{llll}\text { 南 } & 9 & \text { 西 } & 7 \\
\text { 北 } & 5 & \text { 西 } & \\
\text { 北 } & 5 & \text { 西 } \\
\text { 北 } & 3\end{array}$ " & $\begin{array}{l}7 \\
4 \\
3 \\
2\end{array}$ & $\begin{array}{r}1200 \\
150 \\
400 \\
1650 \\
2300\end{array}$ & $\begin{array}{l}24.7 \\
21.9 \\
24.6 \\
15.0 \\
11.3\end{array}$ & $\begin{array}{r}22.5 \\
10.4 \\
13.4 \\
14.4 \\
7.8\end{array}$ & $\begin{array}{r}48.6 \\
6.8 \\
16.3 \\
110.0 \\
203.5\end{array}$ & $\begin{array}{r}53.3 \\
14.4 \\
29.9 \\
114.6 \\
294.9\end{array}$ & $\begin{array}{l}16053 \\
13578 \\
14249 \\
16587 \\
10814\end{array}$ & $\begin{array}{l}12980 \\
12346 \\
18651 \\
12701 \\
10362\end{array}$ & $\begin{array}{r}780.2 \\
92.3 \\
232.3 \\
1824.6 \\
2200.6\end{array}$ & $\begin{array}{r}691.8 \\
177.8 \\
557.7 \\
1455.5 \\
3055.8\end{array}$ \\
\hline $\begin{array}{lll}\text { 北 } & 1 & \text { 西 } \\
\text { 北 } & 1 & \text { 西 } \\
\text { 北 } & 1 & \text { 西 } \\
\text { 西 } & 1\end{array}$ & $\begin{array}{l}3 \\
4 \\
3 \\
4\end{array}$ & $\begin{array}{r}2050 \\
500 \\
2250 \\
350 \\
750\end{array}$ & $\begin{array}{l}12.4 \\
13.7 \\
30.8 \\
10.0 \\
26.2\end{array}$ & $\begin{array}{l}14.4 \\
13.9 \\
14.3 \\
11.0 \\
17.3\end{array}$ & $\begin{array}{r}165.3 \\
36.5 \\
73.1 \\
35.0 \\
28.6\end{array}$ & $\begin{array}{r}142.4 \\
36.0 \\
157.3 \\
31.8 \\
43.4\end{array}$ & $\begin{array}{l}15273 \\
15908 \\
22471 \\
16821 \\
22229\end{array}$ & $\begin{array}{l}12170 \\
13870 \\
20021 \\
14941 \\
22109\end{array}$ & $\begin{array}{r}2524.6 \\
580.6 \\
1642.6 \\
588.7 \\
635.7\end{array}$ & $\begin{array}{r}1733.0 \\
497.3 \\
3149.3 \\
475.1 \\
959.5\end{array}$ \\
\hline $\begin{array}{lll}\text { 南 } & 1 & \text { 西 } \\
\text { 南 } & 1 & \text { 西 } \\
\text { 南 } & 1 & \text { 西 } \\
\text { 石 狩 } & \text { 陸 }\end{array}$ & $\begin{array}{l}4 \\
3 \\
4 \\
\\
\text { 橋 }\end{array}$ & $\begin{array}{r}2050 \\
1200 \\
1150 \\
800 \\
2950\end{array}$ & $\begin{array}{r}17.7 \\
8.3 \\
16.3 \\
32.2 \\
23.9\end{array}$ & $\begin{array}{r}10.9 \\
9.4 \\
15.1 \\
18.5 \\
22.0\end{array}$ & $\begin{array}{r}115.8 \\
144.6 \\
70.6 \\
24.8 \\
123.4\end{array}$ & $\begin{array}{r}188.1 \\
127.7 \\
76.2 \\
43.2 \\
134.1\end{array}$ & $\begin{array}{r}9618 \\
9245 \\
13587 \\
20501 \\
31985\end{array}$ & $\begin{array}{r}7997 \\
8537 \\
17131 \\
13219 \\
21990\end{array}$ & $\begin{array}{r}1113.8 \\
1336.8 \\
959.2 \\
508.4 \\
3946.9\end{array}$ & $\begin{array}{rl}1 & 504.2 \\
1 & 090.2 \\
1 & 305.4 \\
571.1 \\
2948.9\end{array}$ \\
\hline $\begin{array}{cccc}\text { 東 } & 7 \text { 丁 目 踏 } \\
\text { 東 } & & & \\
1 & & \text { 条 } & \\
\text { 豊 } & & \text { 平 } & \text { 林 } \\
\text { 并 } & & \text { 大 } & \text { 林 }\end{array}$ & $\begin{array}{l}\text { 切 } \\
\text { 橋 } \\
\text { 橋 } \\
\text { 橋 } \\
\text { 橋 }\end{array}$ & $\begin{array}{r}900 \\
650 \\
500 \\
3200 \\
950\end{array}$ & $\begin{array}{l}21.4 \\
17.2 \\
21.3 \\
31.9 \\
24.3\end{array}$ & $\begin{array}{l}7.8 \\
24.3 \\
20.5 \\
21.1 \\
26.2\end{array}$ & $\begin{array}{r}42.1 \\
37.8 \\
23.5 \\
100.3 \\
39.1\end{array}$ & $\begin{array}{r}115.4 \\
26.7 \\
24.4 \\
151.7 \\
36.3\end{array}$ & $\begin{array}{r}4346 \\
35641 \\
19747 \\
33510 \\
17989\end{array}$ & $\begin{array}{r}2497 \\
20968 \\
16867 \\
30065 \\
15243\end{array}$ & $\begin{array}{r}183.0 \\
1347.2 \\
464.1 \\
3361.1 \\
703.4\end{array}$ & $\begin{array}{r}288.2 \\
559.8 \\
411.6 \\
4560.9 \\
553.3\end{array}$ \\
\hline $\begin{array}{l}\text { 南 } 9 \text { 西 } \\
\text { 㹸 } \\
\text { 南 } 22 \text { 平条 } \\
\text { 北海学園 } \\
\text { 中 }\end{array}$ & $\begin{array}{l}3 \\
\text { 橋 } \\
\text { 橋 } \\
\text { 脽 } \\
\text { 街 }\end{array}$ & $\begin{array}{r}950 \\
450 \\
650 \\
350 \\
1150\end{array}$ & $\begin{array}{l}25.0 \\
26.2 \\
27.3 \\
25.8 \\
37.3\end{array}$ & $\begin{array}{l}27.2 \\
24.8 \\
32.0 \\
20.9 \\
31.5\end{array}$ & $\begin{array}{l}38.0 \\
17.2 \\
23.8 \\
13.6 \\
30.8\end{array}$ & $\begin{array}{l}34.9 \\
18.1 \\
20.3 \\
16.7 \\
36.5\end{array}$ & $\begin{array}{r}17808 \\
14751 \\
10970 \\
13249 \\
7950\end{array}$ & $\begin{array}{r}15152 \\
12969 \\
8895 \\
10847 \\
7518\end{array}$ & $\begin{array}{r}676.7 \\
253.7 \\
2610.9 \\
180.2 \\
244.9\end{array}$ & $\begin{array}{l}528.8 \\
234.7 \\
180.6 \\
181.1 \\
274.4\end{array}$ \\
\hline $\begin{array}{l}\text { 南 } 22 \text { 条”交差 } \\
\text { 平岸小学校 } \\
\text { 白石中の島線交差 } \\
\text { 上白石小前交差 }\end{array}$ & $\begin{array}{l}\text { 点 } \\
\text { 横 } \\
\text { 点 } \\
\text { 点 }\end{array}$ & $\begin{array}{r}750 \\
3800 \\
1800 \\
1800 \\
1700\end{array}$ & $\begin{array}{l}30.8 \\
29.5 \\
38.0 \\
34.1 \\
25.4\end{array}$ & $\begin{array}{l}30.3 \\
29.4 \\
26.2 \\
36.3 \\
24.2\end{array}$ & $\begin{array}{r}24.4 \\
128.8 \\
47.4 \\
52.8 \\
66.9\end{array}$ & $\begin{array}{r}24.8 \\
129.3 \\
68.7 \\
49.6 \\
70.2\end{array}$ & $\begin{array}{r}10306 \\
13492 \\
8884 \\
23359 \\
6690\end{array}$ & $\begin{array}{r}8669 \\
9942 \\
5718 \\
16018 \\
5118\end{array}$ & $\begin{array}{r}251.5 \\
1737.8 \\
421.1 \\
1233.4 \\
447.6\end{array}$ & $\begin{array}{r}215.0 \\
1285.5 \\
392.8 \\
794.5 \\
359.3\end{array}$ \\
\hline $\begin{array}{lcl}\text { 月 } & \text { 寒 }{ }^{7} \text { 東 } & \text { 丁 } \\
\text { 南 } & 19 & \text { 西 } \\
\text { 南 } & 16 & \text { 西 }\end{array}$ & $\begin{array}{c}\text { 目 } \\
15 \\
7\end{array}$ & $\begin{array}{r}2950 \\
1100 \\
750\end{array}$ & $\begin{array}{l}37.5 \\
35.1 \\
23.3\end{array}$ & $\begin{array}{l}36.4 \\
32.5 \\
22.3\end{array}$ & $\begin{array}{l}78.7 \\
31.3 \\
32.2\end{array}$ & $\begin{array}{l}81.0 \\
33.8 \\
33.6\end{array}$ & $\begin{array}{l}3066 \\
1180 \\
9992\end{array}$ & $\begin{array}{l}2702 \\
2512 \\
7383\end{array}$ & $\begin{array}{r}241.3 \\
36.9 \\
321.7\end{array}$ & $\begin{array}{r}218.9 \\
84.9 \\
248.1\end{array}$ \\
\hline & & & & & & & $\begin{array}{r}751817 \\
100 \%\end{array}$ & $\begin{array}{r}649491 \\
86.3 \%\end{array}$ & $\begin{array}{r}49329.3 \\
100 \%\end{array}$ & $\begin{array}{r}48841.3 \\
99 \%\end{array}$ \\
\hline
\end{tabular}

注 1) 路線與は $1 / 25000$ 札幌都市計画図より測った（単位：m）

注 2) 札幌市都市部画課による実測値（単位: $\mathrm{km} / \mathrm{h}$ )

注 3)

注 4) 路線長を夏期平均区間速度で割った計算值 (単位 : h)

注 5) 路線長を冬期平均区間速度で割った計算値（”）

注 6) 札幌市都市計画課! こ上る実测值（昭和 42 年度交通量調査観測結果表一一昭和 42 年 8 月）（単位：V)

注 7）" " (昭和 43 年度冬期交通量調查集計表一昭和 43 年1月）（"）

注 8）夏期交通仕事量流期交通量に夏期旅行時間をかけた計算值（単位：V·h）

注 9）冬期交通仕事量は冬期交通量に冬期旅行時間をかけた計算值（"）

夏期の 100 に対して冬期のそれは 99 となって,その差 はわずか $1 \%$ にしか過ぎない。もちろん,この一つの事 実から断定することはできないが，もし一つの都市にお いて，夏期とそれに続く冬期に消費される日交通仕事量 が一定であると仮定できるならば，夏期の日交通量 $\Sigma T_{0 k}$ と平均所要旅行時間 $\bar{t}_{0}$, および冬期の平均所要
旅行時間 $\bar{t}$ を調査することによって，冬期の日交通量 $\Sigma T_{k}$ を計算することができる。

$$
\begin{aligned}
& W=\sum_{k} T_{0 k} \cdot t_{0 k}=\sum_{k} T_{k} \cdot t_{k} \\
& \sum_{k} T_{k}=\left(\bar{t}_{0} / \bar{t}\right) \sum_{k} T_{0 k} \cdots \cdots \cdots
\end{aligned}
$$

ゆえに, 夏期の日交通量と冬期の日交通量との差 $\Delta T$ 
は

$$
\Delta T=\sum_{k} T_{0 k}-\sum_{k} T_{k}=\sum_{k} T_{0 k}\left(1-\bar{t}_{0} / \bar{t}\right)
$$

である。街路除雪により,この差を解消し得るとすれ ば,これが交通量差で表わした街路の除雪効果である。

\section{（2）交通量一生産所得関数モデル}

交通量差で表わした除雪効果を，Tinbergen model による道路経済効果推定法にならって, 市民生産所得の 差として表現するために, 交通量一生産所得関数モデル を構成してみよう。

a） 交通量と生産投入要素との関俰

自動車の積載量を一定 $l$, 生産投入要 素を $X$ とすれ ば, 自動車交通量 $T$ と要素 $X$ との間には比例関係が成 立すると考えられる。

$$
\begin{aligned}
& T=m^{\prime}(X / l)+n^{\prime} \ldots \ldots \ldots \ldots . . . \\
& X=l\left(T-n^{\prime}\right) / m^{\prime}=m T+n .
\end{aligned}
$$

ただし, $\left(l / m^{\prime}\right)=m,\left(-l n^{\prime} / m^{\prime}\right)=n$ と置き換える。

すなわち, 生産投大要素が増大すれば, 交通量が比例 して増加する。逆に, 交通量の増加は生産投入要素の増 大を意味するものともいえよう。

一方, 現在のわが国におけ䅉産投入要素の輸送には 自動車交通を欠くことができない。たとえば, 輸送行程 の大部分を鉄道，船舶・航空等によっていても，その両 端には大抵, 自動車が接続しているからである。それで $T=0$ ならば， $X=0$ であるといえる。これより式 (5) において $n=0$ となって,

$$
X=m T
$$

をうる。

\section{b）生産投入要素と生産所得との関係}

生産投入要素と生産所得との関係は, いわゆる生産関 数によって表わされる。

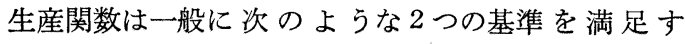
$る^{4)}$ 。

(1) 生産投入要素 $X$ が増加すれば, 生産所得 $Y$ は増 大する (限界生産力は正)。

$$
\frac{\partial Y}{\partial X}>0
$$

(2) しかし, 増加率はてい減する（生産投入要素の収 穫てい減法則)。

$$
\frac{\partial^{2} Y}{\partial X^{2}}<0
$$

これらの条件を満足する関数モデルには,

$$
Y=\alpha X^{\beta} \quad \alpha>0,1>\beta>0
$$

というようなべき関数が考えられる。すなわち,

(1) 限界生産力は正

$$
\frac{\partial Y}{\partial X}=\alpha \cdot \beta X^{\beta-1}>0 \text {. }
$$

(2) 収穫てい減法則

$$
\frac{\partial^{2} Y}{\partial X^{2}}=\alpha \cdot \beta(\beta-1) X^{\beta-2}<0
$$

である。そこで生産関数として式（9）のようなべき関 数を採用するとすれば, これと式 (6) より, 次のよう な交通量と生産所得の関係をうる。

$$
Y=\alpha X^{\beta}=\alpha m^{\beta} \cdot T^{\beta}=a T^{b} \text {. }
$$

すなわち, その地域の交通量 $T$ と, 生産所得 $Y$ との関 倸は, 式 (12) のよ5なべき関数の形であらわされる。 それで筆者は

$$
Y=a T^{b}, a>0,1>b>0 .
$$

を仮に交通量一生産所得関数 モデル（traffic volumeproduct model) と名付けた。

\section{（3）街路除雪の経済効果推定法}

交通量一生産所得関数モデルは，原点をとおり，上に 凸なグラフである。

いま, 積雪により, 旅行時間が $t_{0}$ か $t$ に増加すれ ば, 交通仕事量一定の仮定を置くことによって減少交通 量 $\Delta T$ を式（3）によって計算することができる。

また, この減少に伴って, 交通量一生産所得関数モデ ルが示すように, 生産所得が $Y_{0}$ から $Y$ に減少すると しよう。もし, 道路除雪により旅行時間の増加を押え得 るとすれば，交通量は減少せず，したがって，生産所得 の減少もなくなるわけである。すなわち，この減少を防 ぎ得た生産所得額 $\Delta Y$ が道路除雪の経済的便益であり， 除雪作業に要した費用と比較することによって経済効果 を推定することができる。すなわち，除雪作業に要した 費用を $C$, これによって生じた経済的便益を $B$ とすれ ば,

$$
B=\Delta Y
$$

であって, 費用・便益比率 $a$ は

$$
a=B / C=\Delta Y / C \text {. }
$$

で表わされる。

\section{3. 札幌市中心部における道路除雪の経済効果 推定}

札幌市では毎年，冬になると 4 億円以上にもおよぶ巨 費を投じて除雪を行ない, 道路交通の確保をはかってい る。これはほとんどの市民生活が道路交通にたよってお り，道路交通の途絶はただちに市民生活の阻害につなが っているからである。

除雪はこの道路交通の途絶を解消し，市民生活を平常 に維持するためにはなはだ重要である。筆者はこの重要 さの数量的把握, 特にその経済効果の推定を前章におい て提案した方法により札幌市中心部を例にとり推定して 


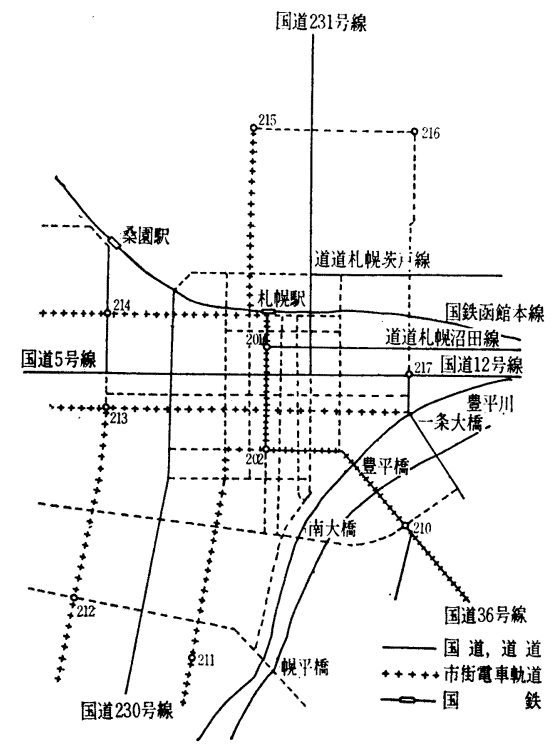

図一4 対象地域と道路網

みた。

a) 推定対象地域

推定対象地域は 図一4 に示すような 札幌市の 中心地 域である。この中心地域には札幌市のすべての交通機関 が集中しており，通勤・通学を目的とするパーソン・ト リップの大部分もこの地域を経過するか，あるいはここ に起終点をもっている。したがって，この地域の交通ま ひは札幌市全域, およびその周辺都市の市民生活に大き な被害を与えることになる。

b) 最低基本道路網と平常生活道路網

国道, 道道, 市街電車軌道, および地域が坬立しない ための三, 三の道路は市民の生存に欠かせない最低の道 路であるから，これを最低基本道路網とし，途絶はあり 得ないものとする。普通, 国道の除雪は北海道開発局が 行ない, 道道は北海道が，市街電車軌道は札幌市交通局 が行なうものである。これらの道路がまったく途絶する と，たとえ，それが一日であろうとも，老人あるいは幼 児に死亡者が出る恐れがある。このほかは平常生活道路 網であり, 前述の最低基本道路網と平常生活道路網との 両方が利用可能になって, はじめて, 平常生活が維持で きるものとする。札幌市建設局の支出になる除雪費は， この平常生活道路網の除雪のために費やされるものであ る。

\section{（1）道路除雪が交通量におよぼす影響}

昭和 43 年度に札幌市が実施した自動車交通起終点調 査 ${ }^{5)}$ のゾーン区分によって, 札幌市の中心部をゾーンに 分割し, それぞれのゾーン・ペアごとの交通量につい
て, 次のような計算手順により, 最低基本道路網だけが 除雪されている場合の交通量 $T$ と, 最低基本道路網, お よび平常生活道路網の両方が除雪されている場合の交通 量 $T_{0}$ との差 $\Delta T$ をもとめることにする。すなわち, この交通量の差 $\Delta T$ が平常生活道路網を除雪したこと によって, 減少を免れた交通量であって, 街路除雪によ る効果と考えられる。

\section{計算手順}

(1) 基本道路網と生活道路網の両方が除雪されている 場合の交通量 (平常交通量) $T_{0}$ を道路網に流し, 交通 仕事量 $W$ を計算する。

(2) 生活道路網は除雪されていないために不通になっ ていると仮定し, 開通している基本道路網だけについ て, 平常交通量 $T_{0}$ より, やや少ない交通量 $T^{\prime}$ を流 し，交通仕事量 $W^{\prime}$ を試算する。

(3) $T^{\prime}$ を加減しながら，(2)の計算を繰り返し，W= $W^{\prime}$ となるような $T^{\prime}$ を見付け，これを基本道路網だけ が除雪されている場合の交通量 $T$ とする。

(4) 平常交通量 $T_{0}$ から基本道路網だけが除雪され ている場合の交通量 $T$ を差し引き, 交通量差 $\Delta T$ を求 める。

これを, それぞれ中心部に関係のあるゾーン・ペアご とに行なうと 表一2 のようになる。すなわち, 総交通 量差は 17692 台である。

\section{表一2 交通豆差で表わした除雪効果}

(昭和 43 年度)

\begin{tabular}{|c|c|c|c|c|}
\hline ゾーン・ペア & 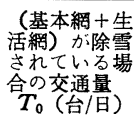 & $\begin{array}{c}\text { 交通仕事量 } \\
W \\
\text { (台・時間) }\end{array}$ & 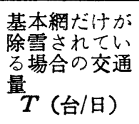 & $\begin{array}{c}\text { 交通量差 } \\
\Delta T=T_{0}-T \\
\quad \text { （台/日） }\end{array}$ \\
\hline $201-202$ & 50772 & 3232 & 47040 & 3732 \\
\hline $210-201$ & 5264 & 371 & 5121 & 143 \\
\hline $210-202$ & 14010 & 1409 & 12498 & 1512 \\
\hline $211-201$ & 9778 & 869 & 9589 & 189 \\
\hline $211-202$ & 33310 & 2578 & 26068 & 7242 \\
\hline $212-202$ & 6679 & 893 & 6637 & 42 \\
\hline $213-201$ & 15859 & 1341 & 15680 & 179 \\
\hline 213--202 & 36138 & 2243 & 35771 & 367 \\
\hline $213-210$ & 2103 & 193 & 2082 & 21 \\
\hline $214-201$ & 12396 & 1077 & 12115 & 281 \\
\hline $214-202$ & 8095 & 962 & 7899 & 196 \\
\hline $215-201$ & 11130 & 808 & 10804 & 326 \\
\hline $215-202$ & 8232 & 516 & 7585 & 647 \\
\hline $216-210$ & 12013 & 1326 & 9615 & 2398 \\
\hline $217-201$ & 13488 & 891 & 13364 & 124 \\
\hline $217-202$ & 16657 & 1416 & 16555 & 102 \\
\hline $217-213$ & 4505 & 581 & 4346 & 159 \\
\hline \multirow[t]{2}{*}{$217-214$} & 2466 & 217 & 2434 & 32 \\
\hline & 262895 & 20923 & 245203 & 17692 \\
\hline
\end{tabular}

\section{（2）札幌市における交通量一生産所得関数モデル}

道路除雪によって生じた便益を交通量の単位, すなわ ち, 台，あるいはトリップ数によって表わすことができ 
た。それでは,この交通量が都市の生産所得の形成にど の程度寄与しているのであろらか。これを知り得れば生 産所得額の変化として道路除雪による経済便益を表現す ることができる。これには交通量一生産所得関数モデル を用いればよい。

交通量一生産所得関数モデルを実際に構成するには同 時期の交通量調查結果と生産所得額とが揃って用意され ていなければならない。ところが札幌市にはこれに利用 できる資料として昭和 37 年 ${ }^{6)}, 40$ 年 $^{7)}$, および 43 年 $^{8)}$ の交通量調查と昭和 35 年から昭和 43 年までの市民所 得統計があるが，このうち同時期の資料が両方共に揃っ ているのは昭和 37 年, 40 年, 43 年の 3 点である。こ れにより交通量一生産所得関数モデルを構成した。な お, 実質日額市民所得は年額市民所得を 365 で割り, さらに札幌市卸売物価指数によって昭和 43 年の金額に 換算したものである(表一3)。

表一3 札幌市の日額市民所得と交通量

\begin{tabular}{|c|c|c|c|c|c|}
\hline & $\begin{array}{c}\text { 年 額 } \\
\text { 市民盟 } \\
\text { (千开) }\end{array}$ & $\begin{array}{l}\text { 旦 額 } \\
\text { 市民所 } \\
\text { (千开) }\end{array}$ & $\mid \begin{array}{c}\text { 物価指数 } \\
\left(\begin{array}{l}\text { 照 } 43 \\
=100\end{array}\right)\end{array}$ & $\begin{array}{c}\text { 実質旦額 } \\
\text { 市梊 } \\
\text { (千开) }\end{array}$ & $\begin{array}{c}\text { 交 通量 } \\
\text { (台) }\end{array}$ \\
\hline 昭和 37 年 & 165126983 & 452403 & 86.98 & 520100 & 206849 \\
\hline 昭和 40 年 & 257866288 & 706483 & 93.40 & 756352 & 395807 \\
\hline 昭和 43 年 & 406540514 & 1113810 & 100.00 & 1113810 & 775565 \\
\hline
\end{tabular}

注 1) 年額市民所得は札幌市調査統計課 : 札幌市民所得推計報告によっ た。

注 2) 日額市民所得 $=$ 年額市民所得 $/ 365$

注 3）物価指数は北海道通商産業統計年報による札幌市卸売物価指数を 昭和 43 年 $=100.00$ としたものになおした。

注 4）実質日額市民所得二日額市民所得/物価指数

注 5) 札幌市域（手稲町孔含む）の総自動車交通量（台/日）

これらの資料を用いて式 (13) のようなべき関数をあ てはめれば,

$$
\begin{aligned}
& Y=451.259 T^{0.576} \ldots \ldots \\
& \frac{d Y}{d T}=259.925 T^{-0.424}
\end{aligned}
$$

をうる(図一5)。

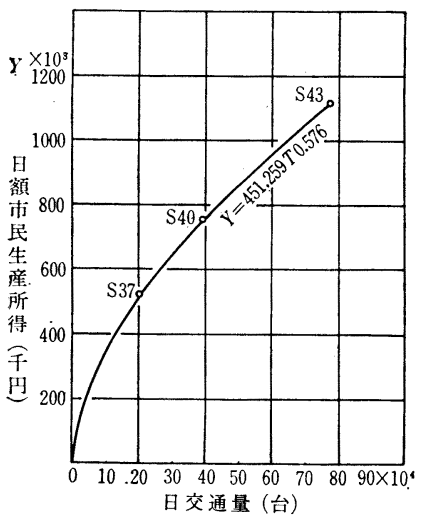

図一5 札幌市における交通量 生産所得関数モデル
この交通量一生産 所得関数モデルはわ ずかに 3 力年の資料 による裏付けしかな く, 信頼がおけない のではなかろらかと いら非難が生ずるか もしれない。しか し,このモデルは任 意の曲線を, ただ単 に最小二乗法で当て はめたものではな く, 前章において述 べたような, 理論的
裹付けがある。さらにこの用い方は, 内挿法でかつ, 昭和 43 年の点のごく近傍の值について用いるのである から,この論文の目的には十分に役立つものと思われる。

\section{（3）費用・便益比率および超過便益額}

a）道路除雪によって生ずる便益額

除雪を完全にすればするほど, 自動車交通は平常時の 交通量に近づき，市民生活も常態に復するから，除雪し なければ生じたであろう損害を軽減できる。この軽減額 が除雪の便益額と考えられることは前述のとおりであ る。

（1）では札幌市中心部の道路除雪の影響として， 17692 台/日を算出したが, これは市民所得にどの程度 のインパクトを与えるのであろらか。これを見積るに は，(2) において構成した交通量一生産所得関数モデル を用いればよい。

$$
\begin{aligned}
\text { 式 }(d Y / d T)=259.925 T^{-0.424} \text { から } \\
(d Y / d T)_{T=775,565}=0.827 \text { (千円/台) } \\
(d Y / d T)_{T=757,873}=0.835 \text { (千円/台) }
\end{aligned}
$$

が得られる。すなわち, 日交通量 775565 台（昭和 43 年度) の場合, 交通量 1 台当り, 827 円の生産所得の創 出にあたっているし,これより $\Delta T=17692$ 台を差し引 いた 757873 台の場合には 835 円の創出にあたってい ることになる。昭和 43 年度の実質日額市民所得は $Y=$ 1113810 千円, 日交通量は $T=775565$ 台であるから, $(Y / T)=1.4361$ 千円で, 弾力性 $\eta$ は

$$
\eta=\left(\frac{d Y}{d T}\right) /\left(\frac{Y}{T}\right)=\frac{0.827}{1.4361}=0.576
$$

であり, 交通量一生産所得関数モデル式 (16) の $T$ の指 数 $b=0.576$ に等しい。

さて, 平常生活道路網を除雪しなければ交通量は 757873 台に減少するが, これに伴って生産所得はいく らに低下するか。これは弾力性 $\eta$ を用いれば次式によ り簡単に計算できる。

式 (20) より

$$
Y=\frac{(d Y / d T) \cdot T}{\eta}=\frac{(d Y / d T) \cdot T}{b}
$$

$T=757873$ 台では

$$
Y_{T=757873}=\frac{0.835 \times 757873}{0.576}=1098653 \text { 千円 }
$$

である。それで市民生産所得の低下額は

$$
\Delta Y=Y_{T=775565}-Y_{T=757873}=15157 \text { 千円 }
$$

である。ところが，この低下額は除雪によって防止でき るので,この額が, すなわち, 便益額 $B=\Delta Y$ といえる のである。 
b）費用・便益比率

札幌市道路維持課の実績調查によると, 図一2 に示さ れる範囲の道路除雪費は市職員の人件費, 諸掛りを加え て, 昭和 43 年度には 240000 千円であった。また一 方, 除雪期間は 12 月， 1 月， 2 月の 3 か月であり， 90 日であるから, 1 日当りの除雪費 $C$ は

$$
C=240 \text { 000/90=2 } 667 \text { 千円. }
$$

である。それで

$$
\text { 費用・便益比率 } a=(B / C)=\frac{15157}{2667}=5.7
$$

と計算できる。

ここで問題となるのは, 市民生活の最低を維持するに 要する最低基本道路網のとり方である。これの多少によ り, 便益額も相当に変わってくるからである。この研究 においては札幌市道路維持課，および都市計画課の意見 を参考にして 図一4 のようなものをとった。もし基本 網に変更があったとしても，計算の手続きはまったく以 上と同様でよい。

\section{4. むす び}

本論文においては，道路経済効果推定法の原点にもど り, 自動車交通流という現象システムと, 都市経済構造 という現象システムの内容をまず研究した。その結果, 前者においては「交通仕事量一定の仮説」をたて, 後者 においては交通量一生産所得関数モデルを構成して, こ の両者の有機的結合によって経済的便益を貨幣単位によ って算出することを試みたのである。そして，そのアウ ト・プットを費用, 便益比率といら在来から認められて いる評価システムのイン・プットとして投入し，そのア ウト・プットをもって，道路の経済効果とする手法を提 案したのである。最後に, この手法を昭和 43 年度にお
ける，札幌市中心部の道路除雪の場合に適汽し，費用・ 便益比率を 5.7 と推定した。

この手法は, 在来の方法からいえば総合的推定法の流 れを汲むもので，その経済効果の及ぶ範囲が部分的でな く，影響時間も瞬時でない場合にのみ応用できるもので ある。もし，その経済効果の及ぶ範囲が部分的で，瞬時 のものであれば，その道路を新設，改良，あるいは復旧 しなければ生じたであろら余分の交通仕事量（交通量 $\times$ 平均旅行時間）を計算し，これを基として直接効果を推 定することで十分と考える。なお，ここに提案した手法 の要点となっているものは「交通仕事量一定の仮説」と 「交通量一生産所得関数モデル」であり，今後の問題も やはりここに残されている。すなわち，これらの仮説， およびモデルは，まだ実証例に乏しく，また構成に用い た資料が少ないからである。

この研究を遂行するに当っては，終始，北海道大学小 川博三教授のご指導を賜わった。また，札幌市都市計画 課からは貴重な資料の提供を受けた。記して深く謝意を 表する。

1）増井健一・佐竹義昌 : 交通経済論, pp. $236 \sim 246$, 有斐 閣, 昭 44

2）札幌市建設局計画部都市計画課：札幌市内主要街路走行 速度調査, 昭 42.8

3）札幌市建設局計画部都市計画課：昭和 42 年度冬期交通量 調査観測結果表

4) 藤野志朗 : 生産分析 (近代 経 済学講座, 計量分析篇 1 , p. 131 , 有斐閣)

5) 北海道開発局道路計画課 : 昭和 43 年度都市周辺道路網調 查報告書（札幌・小樽地区），昭和 44 年 9 月

6) 建設省都市局 : 昭和 37 年度都市起終点交通調 査報 告 書 (その 1), 昭 39

7）建設省都市局：昭和 40 年度都市自動車起終点 調査報告 書, 昭 41

8）札幌市建設局計画部都市計画課 : 昭和 43 年度札幌広域都 市圈 O.D 表, 昭 44

(1971.3.6 - 受付) 